\title{
Library automation: \\ strategies for library human resource management
}

The Authors

KURUPPU ARACHCHI, THEJA

BSC (Hons.)(Ruhuna)

Graduate Student, Faculty of Graduate Studies, University of Colombo

DE SILVA, WRG

B.A. (Cylon), M.Lib. (Monash), ALA

Consultant Librarian, Bandaranayaka Centre for Intemational studies

Abstract

This article examines the automation processes at University libraries and the new managerial issues coming on in this technological era. A survey was used to ascertain the library automation practices in University libraries and to determine important managerial functions for working with library staff. All the university libraries including faculty libraries were deemed as the study population. The results showed that library catalogue had been computerized in most of the University libraries (89.25\%). Acquisition, circulation, serials contro/s, theses 
and dissertations processing. selective dissemination of information and interlibrary loans were identified as the processes that need improvements with new technology. The study further indicated that shared motivating vision, open communication, participative management, appropriate staffing and training were important strategies for working with library staff, motivating them to provide efficient and effective service in the new technological environment.

\section{Keywords}

Library automation, library management, change management, human resource management, university libranies

\section{Introduction}

Automation is a technological change that replaces people with machines. Automation of library functions has revolutionized library activities. It enables libraries to provide an effective service while saving the employee time by transferring low-level, repetitive operations to a machine. Library automation systems have been developed for library in-house operations including acquisition (identifying, ordering, receiving and paying for library resources), cataloguing (arranging materials together by subjects and providing access to them), circulation (making library resources available to user by lending), serials controls, theses and dissertations processing and reference services such as selective dissemination of information and interlibrary loans. 
While changing from traditional library services to automated library services, new equipments and processes are introduced changing the work process or work activities in the library. It has changed the nature and the scope of library work. Introduction of computer library systems cause technological organizational and sociological changes. The most important of these is sociological changes. Introduction of new technology to library services changes the relationship between the library staff and their work. It must be planned for reducing the potential for resistance to change. The challenge to library managers is to manage and develop library human resources not to master the functionalities of automation. Therefore the purpose of this study was to identify the computerized in house operations in University libraries in Sri Lanka and the management strategies that were important to make these automation projects successful.

\section{Management of library human resources}

A successful library automation project depends on good management. Library management requires attention to a wide variety of strategies or techniques in embracing change caused by library automation. The most important is management and development of library human resources. How library managers deal with the major factors that need to be considered in this changing environment, will largely determine how successful that change will be.

Some of the important strategies for managing human resources during automation change management are;

01. Establishing a shared motivating vision

02. Creating open communication and collaboration culture

03. Participative management

04. Appropriate staffing

05. Appropriate training and coaching for people involved 


\section{Shared motivating vision}

An organization needs a clear vision of what it wants to accomplish in terms of a new library automation system. The vision should be established so that the role of library automation will result in a more effective and efficient library service. For achieving this library manager must communicate the vision and develop a shared need for change and mobilize people.

\section{Open communication}

Automation change should be communicated in a way that staff will see it as a positive thing for both the library and themselves. According to Hellriegel and Slocum (1982: 699) organizational change can succeed only if the manager understands the resistance that will be encountered from individuals and the organization. Communication of information is important to create a climate of trust and openness that minimize uncertainty and reduce resistance.

If the employees can be informed about the need for change they will be more likely to help with its implementation (Ritson and Marsden, 2001:327). According to Morgan (2001) one way to help library staff deal with continuous change is for them to become more involved in strategic issues or at least to be strategically aware. Strategy can be discussed in terms that are relevant to the staff-concerned-jargon-free and making relevant connections without being patronizing.

Employees can be educated about the change through one-to-one discussions, presentations, meetings, or memos and reports. Posing changes without their co_operation do not give good results. Healthy 
debates can be organized to discuss the merits and demerits of change before introducing the change.

\section{Participative management}

Participation reduces uncertainty and leads to commitment. It has been identified that the people who participate in making decisions tends to be more committed to the change process than those who are not involved in decision making. Also taking their views into account may enhance the effectiveness of the change programme. Employees, who are involved in the change process, are in a better position to understand the need for change and are motivated to support change. Therefore they are less likely to resist it.

Sykes (1991) states that, library automation will succeed best where participative management is practiced. According to Ritson and Marsden, (2001:327) participation of employees in decision making and taking their views into consideration will result in design of an inappropriate change programme.

\section{Appropriate staffing, training and coaching}

According to Pandey (1999: 105) the selection and appointment of library staff should be done very carefully, because much of the success of the library staff member on the job in a library depends upon skillful personal administration. After appointment the library needs to ensure that new staff and trained in their duties and that the staff improves their activities. The existing staff should be trained in the use of new appliances and mechanics. 
Thompson (1990) points out three facets of administration of training that are vitally important: the vendor of the system must be haeavily involved in training; as many staff as possible must be given a detailed training in the whole system; as much of the training as possible must be given before system implementation. According to Sykes (1991) automation training must emphasize jobs and purposes rather than technology and hardware; it should allow for different learning styles be conducted informally in small groups and include hand-on experience.

\section{Results and discussion}

For determining the present state of library automation programs and relevant human resource management issues a survey was conducted. Only University libraries were questioned. 28 of 35 university libraries responded to the questionnaire $(80 \%)$. From the high rate of return and the comments, it is evident that many libraries are very much concerned with this issue. 


\section{Library automation}

Table 1 Summaries the findings on library automation programs at University libraries in Sri Lanka

Table 1. Computerised in-house operations in university libraries

\begin{tabular}{|l|c|}
\hline \multicolumn{1}{|c|}{ Computerised in-house operations } & $\begin{array}{c}\text { Percentage of University } \\
\text { Libraries }\end{array}$ \\
\hline Cataloguing & 89.25 \\
\hline Acquisitions & 42.80 \\
\hline Serials control & 24.95 \\
\hline Inter-library loans & 17.80 \\
\hline Circulation & 14.20 \\
\hline Selective dissemination of information & 14.20 \\
\hline These and dissertation processing & 10.60 \\
\hline
\end{tabular}




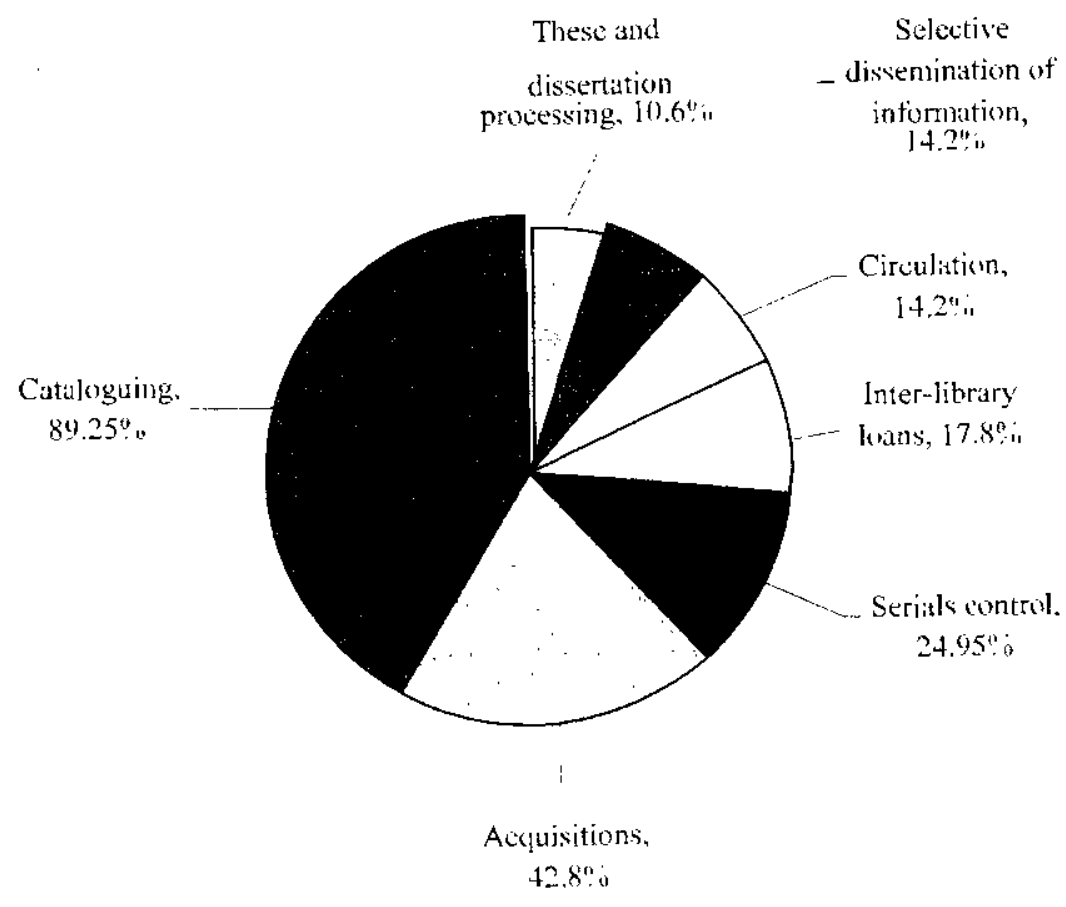

Chart 1. Computerized in-house operations in

University libraries

It was clear from the findings that cataloguing of library resources had been computerized in $89.25 \%$ University libraries. Acquisition had been computerized in $42.8 \%$ University libraries. Only $25 \%$ University libraries had computerized the serials control. Circulation of library resources had been computerized in $14.2 \%$ University libraries. 


\section{Human resource management}

From the data it appears that automation of library in-house operations in most of the libraries are yet to be completed with acquisition, circulation, serials control etc. Therefore the experienced management issues during implementation of library automation systems are important for successful management of future work.

Each respondent was asked to state the level of importance of the attached strategies for human resource management during automation change management.

Table 2. Strategies for successful human resource management during implementation of library automation systams

\begin{tabular}{|c|c|c|c|c|c|c|c|c|}
\hline 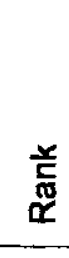 & 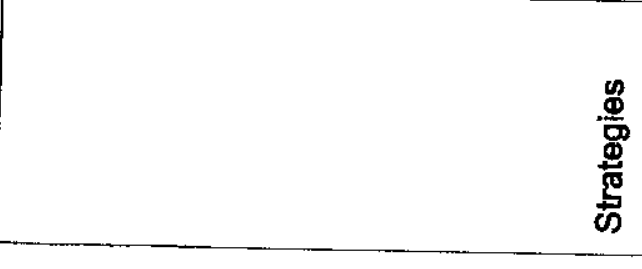 & 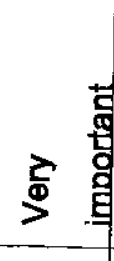 & 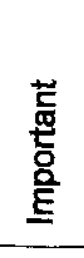 & 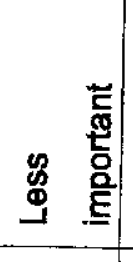 & 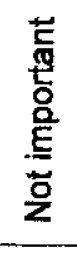 & $w$ & o & $\frac{2}{2}$ \\
\hline & Weight/factor & 3 & 2 & 1 & 0 & & & \\
\hline 1 & Establishing a shared motivating vision & 18 & 8 & - & - & 70 & 26 & 2.69 \\
\hline 2 & $\begin{array}{l}\text { Appropriate training and coaching for } \\
\text { people involved }\end{array}$ & 16 & 10 & - & - & 68 & 26 & 2.61 \\
\hline 3 & Appropriate Staffing & 18 & 9 & - & 1 & 72 & 28 & 2.57 \\
\hline 4 & $\begin{array}{l}\text { Encouraging the participation of staff at } \\
\text { all levels }\end{array}$ & 13 & 11 & 1 & - & 62 & 25 & 2.48 \\
\hline 5 & $\begin{array}{l}\text { Creating open communication and } \\
\text { collaboration culture }\end{array}$ & 11 & 12 & 4 & & 61 & 27 & 2.25 \\
\hline
\end{tabular}


Responses for management strategies for working with library staff members during library automation process are summarised in Table 2 . A likert scale was adopted using four point $0-3$ likert scale ranging from not important $(0)$ to very important (3) for further analysis of the level of importance of the strategies. The likert scores for all the strategies investigated were higher than 2 . The overall likert score is 2.52 . Three or $60 \%$ of the strategies including establishing a shared motivating vision, appropriate training and coaching for people involved, appropriate staffing were above the mean while the remaining two or $40 \%$ of the strategies were below the mean score.

According to the results, establishing a shared motivating vision, appropriate training and coaching for people involved, appropriate staffing, encouraging the participation of staff at all levels and creating open communication and collaborate culture were accepted as important strategies for successful implementation of change during library automation, through creating awareness of the library staff, and staff satisfaction in their work. 
Chart 2. Strategies for successful human resource management during implementation of hibrary automation systems

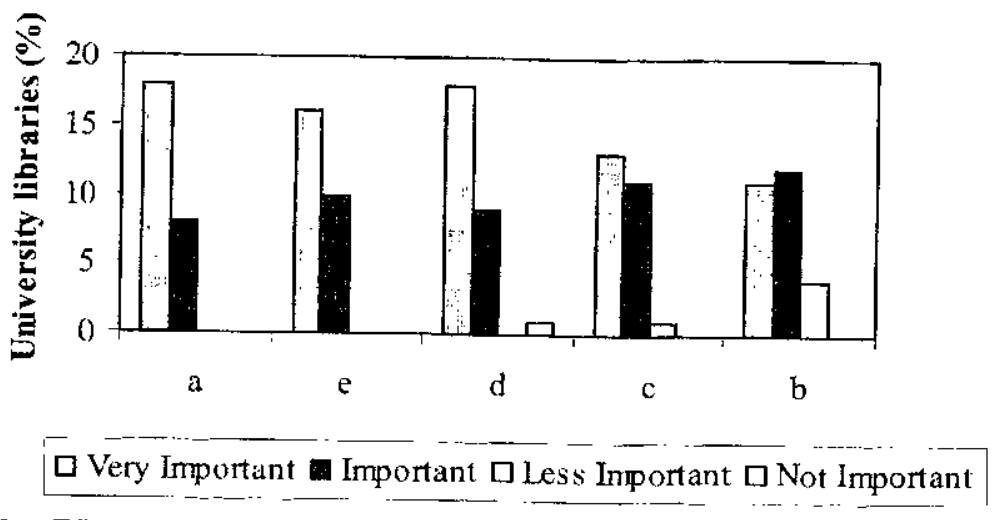

a Establishing a shared motivating vision

b Appropriating training and coaching for people involved

c Appropriate Staffing

d Encouraging the participation of staff at all levels

e Creating open Communication and Collaboration culture 


\section{Recommendations}

Automated circulation, serials control, theses and dissertation processing and acquisition systems should be introduced to other university libraries also to maintain effective services to the readers.

The existing inter-library loan system and selective dissemination of information should be developed using new information technology.

Establishing a shared motivating vision, open communication, participative management, appropriate staffing and training are important to practice for human resource management in libraries and for making library automation programs successful. 


\section{References}

Hellriegel, D. and Slocum, Jr J. W., (1982) Management $3^{\text {rd }}$ ed. AddisonWesley Publishing Company, Philippines. pp 655-723.

Morgan, S., (2001) Change in university libraries: Don't forget people. Library Management. $22 \mathrm{pp} 1 / 2$

Pandey, S. K. ed. (1999) Encyclopediaof library automation systems and networks. Vol. 4: Organization of library automation. ANMOL Publications PVT. LTD., New Delhi.

Ritson, N. and Marsden A., (2001) Organizational Management Viva Books, New Delhi. pp. 299-327.

Sykes, P., (1991) Automation and non-professional staff: The neglected majority. Library Management. 12:3.

Thompson, V., (1990) Training staff for newly installed automated circulation systems. Library Management. 11:5. 